\title{
FIRM-SPECIFIC HUMAN CAPITAL INVESTMENTS AS A SIGNAL OF GENERAL VALUE: REVISITING ASSUMPTIONS ABOUT HUMAN CAPITAL AND HOW IT IS \\ r \\ MANAGED
}

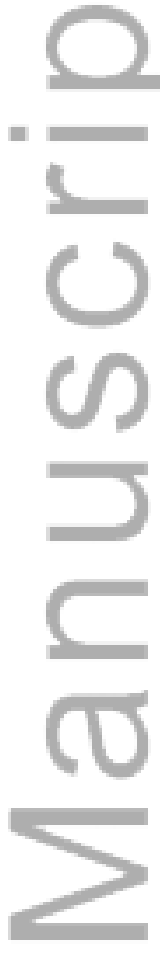

(

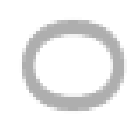

$+$

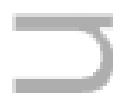

\author{
Shad S. Morris \\ Marriott School of Management \\ Brigham Young University \\ morris@byu.edu \\ Sharon A. Alvarez \\ Daniels College of Business \\ University of Denver \\ sharon.alvarez@du.edu
}

Jay B. Barney

David Eccles School of Business

University of Utah

jay.barney@eccles.utah.edu

Janice C. Molloy

School of Management

University of Bath

molloyic@umich.edu

Running head: Firm-Specific Human Capital as a Signal of General Value

This is the author manuscript accepted for publication and has undergone full peer review but has not been through the copyediting, typesetting, pagination and proofreading process, which may lead to differences between this version and the Version of Record. Please cite this article as doi: 10.1002/smj.2521

This article is protected by copyright. All rights reserved. 
Key words: human capital, human resource management, value appropriation, competitive advantage, market signaling

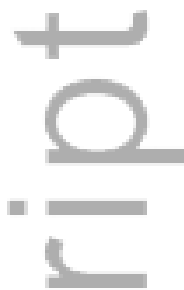

Abstract

\section{Research Summary:}

Prior scholarship has assumed that firm-specific and general human capital can be analyzed separately. This paper argues that, in some settings, this is not the case because prior firmspecific human capital investments can be a market signal of an individual's willingness and ability to make such investments in the future. As such, the willingness and ability to make firmspecific investments is a type of general human capital that links firm-specific and general human capital in important ways. The paper develops theory about these investments, market signals, and value appropriation. Then the paper examines implications for human resource management and several important questions in the field of strategic management, including theories of the firm and microfoundations of competitive advantage.

\section{Managerial Summary:}

While managers don't often use the terms firm-specific and general skills, they certainly recognize that investments employees make in their skill sets are more or less relevant to a specific firm. For instance, investing in specific relationships within a firm or learning a firm's proprietary software would be considered firm-specific investments. While such skills may seem relevant only to the particular firm in which they were invested, these investments may also send valuable signals to competing firms that such employees are willing and able to make similar investments elsewhere. Hence, managers should be interested in determining if a potential hire has made prior firm-specific investments to help them know if that person might be likely to make such investments in their future place of employment.

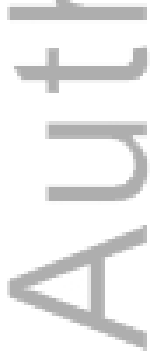


Can general and firm-specific human capital be analyzed separately? Scholars have traditionally viewed general and firm-specific human capital as separate investments that influence who is more likely to appropriate the value created from the human capital—the firm or the employee (Chadwick, 2016; Hatch and Dyer, 2004; Molloy and Barney, 2015; Ployhart and Moliterno, 2011; Wright, Dunford, and Snell, 2001; Wang, He, and Mahoney, 2009). However, these views may not be consistent with reality. Increasing evidence points to conditions under which firm-specific human capital investments signal the existence of valuable, but often difficult to observe, general human capital: a person's willingness and ability to make firm-specific investments (Campbell, Coff, and Kryscynski, 2012; Lazear, 2003). Because prior firm-specific human capital investments can act as a signal of this general human capital, these two types of human capital can be intimately linked, and their implications for firms and employees cannot be understood independent of one another.

Recognition of this possible relationship between firm-specific human capital and general human capital has a variety of important implications that are inconsistent with prior theoretical work. For example, where prior work suggests that firms will appropriate most of the value created by the firm-specific investments made by their employees (Becker, 1964), the link between firm-specific and general human capital described in this paper suggests conditions under which employees can appropriate much of this value. Moreover, where prior work has emphasized how high levels of firm-specific investment reduces employee mobility (Campbell et al., 2012), this paper suggests conditions under which these investments will increase employee mobility. The link between firm-specific and general human capital can also have an impact on 
the kinds of human resource practices a firm is likely to adopt, and on the effectiveness of those practices.

The paper begins by describing how prior firm-specific investments can act as a signal of an employee's willingness and ability to make these investments in the future, and how this willingness and ability is a form of general human capital. It then examines how compensation and cultural factors might reduce the effectiveness of the signal associated with these investments. Next, it describes some of the implications of these arguments for human resource practices within a firm. Implications of these arguments for theories of the firm and for the relationship between human capital and competitive advantage are presented in the discussion.

\section{HUMAN CAPITAL VISIBILITY AND VALUE APPROPRIATION}

Much of the prior work on human capital implicitly assumes that the type (i.e., general or specific), quality, and amount of human capital an individual possesses are observable at low cost (e.g., Oldroyd and Morris, 2012). Of course, this is not always the case. Some types of human capital may be more visible than others.

When a particular type of human capital is less visible, individuals may seek ways to make their possession of this human capital clear to potential employers. One way to do so is to make investments that can serve as a market signal of this less visible human capital. To be an effective market signal, this investment must, first, be highly correlated with the costly to observe human capital; and second, it must be less costly for those with this unobservable human capital to make these investments than it is for those without this human capital (Spence, 1973). 
For example, a college education can be an effective market signal of an often difficult to assess human capital attribute: intelligence. College is an effective signal because intelligence is highly correlated with the ability to complete college and it is less difficult (costly) for a highly intelligent person to complete college than a less intelligent person (Spence, 1973).

\section{The Willingness and Ability to Make Firm-Specific Investments}

One type of general human capital that may be costly to observe is an employee's willingness and ability to make firm-specific investments that are above and beyond what is normally required for the job. Such investments are often seen as discretionary in nature. Examples might include an employee that learns how to work with many different teams of employees within a firm over the course of several years; an employee who learns how to use a firm's proprietary software to generate a string of innovations; and an employee who learns how to coordinate resources in a firm to address diverse customer needs over time.

It is not hard to see how this type of human capital could be very valuable in a firm, by redueing that firm's costs or increasing its revenues beyond what would be the case if a firm did not have access to this human capital (Barney, 1991). It is also not hard to see that this type of human capital is likely to be valuable in most organizational settings, that is, it is a form of general human capital (Becker, 1964). This is the case even though this general human capital is manifested through the firm-specific investments it generates. Finally, because the willingness and ability to make firm specific investments is a form of general human capital, prior theory suggests that, as long as labor markets are reasonably competitive, that employees will be able to appropriate much of the value created by this human capital (Molloy and Barney, 2015). 
Despite the potential importance of an employee's willingness and ability to make firmspecific human capital investments, it may sometimes be difficult for potential employers to observe this form of human capital. This is mostly because this general human capital is manifest through actions taken within the boundaries of an employee's current firm. Potential employers may try to gather information about a perspective employee's prior firm-specific investments through interviews, formal references, informal conversations with colleagues, personality assessments, and by hiring executive search/recruiting firms (Mackey, Molloy \& Morris, 2013). Nevertheless, it can still be difficult and costly to assess someone's willingness and ability to make firm-specific investments when those investments are "shielded" by another firm's boundary.

\section{Market Signals of the Willingness and Ability to Make Firm-Specific Investments}

When an employee's willingness and ability to make firm-specific investments is costly to observe, employees with this general human capital have an incentive to invest in market signals of its existence. These market signals can have an impact on the extent to which employees with this general human capital can appropriate its value (Molloy et al., 2015), and can also have an impact on employee mobility.

One obvious signal of the willingness and ability of individuals to make firm-specific investments is a pattern of such investments made by this individual in the past. In general, future behavior is highly correlated with past behavior (Bentler and Speckart, 1979; Janz, 1992). Moreover, in many settings, it is usually less costly for those with the willingness and ability to 
make firm-specific investments to actually make such investments. For these reasons, a pattern of past firm-specific human capital investments act as a signal of an employee's willingness and ability to make such investments in the future.

Taken together, these arguments suggest our first proposition:

Proposition 1: To the extent that past firm-specific human capital investments by employees act as a signal an employee's willingness and ability to make firm-specific investments, employees will appropriate more of the value they create.



\section{Explicit Incentives to Make Firm-Specific Human Capital Investments}

Of course, incumbent employers would like their employees to make firm-specific human capital investments, but to do so in a way that does not send strong signals to potential employers about their willingness and ability to make such discretionary investments (Gardner, 2005). In this way, more of the value created by an employee's general human capital is likely to be appropriated by the firm. Indeed, if a firm has bargaining advantages in its relationship with its employees, these prior firm-specific investments can be a source of competitive advantage for a firm (Barney, 1986).

Indeed, firms can implement policies that reduce the efficacy of any signals of an employee's willingness and ability to make firm-specific investments. These efforts should enable a firm to appropriate more of the economic value created by this general human capital. These policies include compensating employees for making firm-specific human capital investments, and developing an organizational culture that fosters these kinds of investments. 
Numerous scholars, both in human resources (HR) (Chadwick and Dabu, 2009; Kang, Morris, and Snell, 2007) and strategic management (Wang, et al., 2009), have observed that firms can compensate employees for making firm-specific human capital investments. This compensation can take the form of wages and bonuses (Carmichael, 1983). The logic behind these compensation schemes is straightforward: firm-specific investments have the potential to be a source of competitive advantage for a firm, so, as long as the cost of incentives is less than the value the firm-specific investments creates, incenting employees to make these investments may enhance a firm's performance (Wang et al., 2009).

Ironically, explicitly compensating employees for making firm-specific human capital investments reduces the effectiveness of these investments as a signal of an employee's willingness and ability to make such investments in the future. This is because such compensation schemes reduce the cost of making firm-specific investments both for those employees that are willing and able to make such investments-independent of compensation for doing so - and employees who make these investments because of the explicit compensation the firm is offering. In this setting, potential employers cannot tell the difference between this general human capital and those who are only responding to a firm's incentive system.

This latter group of employees is likely to make firm-specific investments in future employers' firms when these employers use compensation schemes similar to those used by prior employers. In this sense, these employees' firm-specific human capital investments in their current firm do not signal the existence of a generally valuable form of human capital—-the 
willingness and ability to make firm-specific investments. Taken together, these observations lead to proposition 2 .

Proposition 2: Potential employers will find prior firm-specific human capital investments a more effective signal of an employee's willingness and ability to make firm-specific investments when the current employer's compensation system does not explicitly reward such investments.

$=$

From the point of view of the argument developed in this paper, compensating employees for making firm-specific human capital investments reduces the effectiveness of a market signal of an important aspect of an employee's general human capital. This means that employees will not be able to use these market signals to appropriate the value of this general human capital, even if labor markets are reasonably competitive (Molloy et al., 2015).

In such settings, a bi-lateral monopoly emerges between the employee and the firm, and how the value created by these firm-specific investments is appropriated depends on negotiating skills and bargaining power of each party (Peteraf, 1993). The result of this negotiation is the level of compensation that employees receive for making firm-specific investments. However, because no market signal is sent, the firm may avoid paying the full value of general human capital to its employees who are willing and able to make firm-specific investments. In other words, the compensation policy camouflages those employees with this general human capital, and makes it possible for the firm to appropriate more of the value of this human capital than would be the case without the compensation policy in place, i.e., with a clear market signal of the value of this general human capital. 


\section{Organizational Culture and the Value of Market Signals}

Employees may receive explicit compensation for making firm-specific investments. However, an organization's culture can also have an impact on the efficacy of market signals about the willingness and ability of individuals to make firm specific investments.

An organization's culture is the complex set of values, beliefs, assumptions, and symbols

$=$

that define the way in which a firm conducts business (Barney, 1986b). Cultures can guide

interactions between firms and employees (Louis, 1983). Sometimes, an organization's culture

can encourage employees to make more valuable firm-specific investments than they would

otherwise make. In this sense, organizational culture-just like financial incentives — can reduce

the cost for those without the willingness and ability to make firm-specific human capital

investments to make those investments. In this setting, prior firm-specific investments lose some

of their signalling value since other firms cannot determine if those investments stem from an

employee's general human capital or, instead, result from the culture of the firm within which an employee is operating (Groysberg, Lee, Nanda, 2008).

In this context, organizational culture and firm-specific human capital investments can be co-specialized assets, i.e., the existence of a particular type of culture increases the likelihood of making firm-specific human capital investments, and making such investments tends to reinforce the existence of a particular type of organizational culture.

Of course, these organizational cultures can also attract employees who are willing and

able to make firm-specific investments. In this way, being hired by a firm with such a culture can be a signal of the existence of this type of general human capital. However, once these 
employees join such a firm, the signalling value of any firm-specific investments they make in this firm falls since, as before, other firms cannot tell whether these investments reflect an employee's underlying general human capital or are induced by the unique culture of the firm where they work (Coff and Kryscynski, 2011; Hatch et al., 2004). Taken together, these observations lead to proposition 3 :

Proposition 3: Potential employers will find prior firm-specific human capital investments a more effective signal of an employee's willingness and ability to make firm-specific investments when the current employer's culture does not foster such investments.

\section{IMPLICATIONS FOR HUMAN RESOURCE MANAGEMENT}

The arguments presented in this paper have a variety of implications for human resource management practices in firms. Three of these implications are discussed here.

\section{Will Employees Make Firm-specific Investments?}

Prior theory (Becker, 1964) suggests that employees will often be willing to make investments in general human capital, especially when they are operating in reasonably competitive labor markets (Molloy et al., 2015), because employees can appropriate most of the value of this general human capital in such markets. The same theory suggests that employees will be reluctant to make firm-specific investments, because market dynamics make it unlikely that they will be able to appropriate much of the value of these investments. It follows that firms will often need to incentivize employees to make firm-specific human capital investments. 
The market signaling logic presented here has very different implications. First, it suggests that - to the extent that prior firm-specific human capital investments act as a signal of an employee's willingness and ability to make these investments in the future - that employees have an incentive to make these specific investments. This is because this willingness and ability is a form of general human capital, and - if labor markets are reasonably competitiveemployees will appropriate much of the value of this general human capital. Second, it suggests that the incentive to make these investments may actually be stronger if a firm does not directly compensate an employee for doing so. This is because such forms of compensation can obscure the market signal about an employee's general human capital.

Taken together, these arguments suggest that employees who are willing and able to make firm-specific investments will often find it in their self-interest to do so. This is especially likely when these investments act as an effective signal. Thus, employee firm-specific investments are likely to be more common then what has been suggested in previous theory.

This theory also suggests that, to the extent that prior firm-specific investments act as a market signal of this form of general human capital, that these investments should increase employee mobility - as employees seek to appropriate more of the value of their general human capital_rather than less employee mobility.

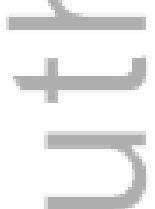

\section{How Will Firms Respond?}


Traditional theory suggests that profit maximizing firms want their employees to make firmspecific investments, because these investments can be a source of competitive advantage. However, to the extent that an employee's prior firm-specific investments act as a signal of their willingness and ability to make firm-specific human capital investments in the future, the ability of the firm to appropriate the value of these specific investments falls. Thus, to increase their ability to appropriate the value of the firm-specific investments made by its employees, firms may engage in activities designed to obscure the extent to which prior investments provide information about this aspect of an employee's general human capital. Explicitly compensating an employee for making firm-specific investments and building a culture that fosters firmspecific investments both accomplish this objective, and effectively reduces the ability of the employee to appropriate the full value that their willingness and ability to make firm-specific investments creates for a firm.

\section{How Will Employees Respond to these Firm Responses?}

Recognizing that their ability to appropriate the full value of their willingness and ability to make firm-specific investments is reduced by a firm explicitly compensating employees from making these investments and by a firm creating an organizational culture that fosters these investments, individuals with this form of general human capital may be reluctant to work for firms with these human resource policies. Instead—other things being equal—individuals with this form of general human capital may prefer to work at companies where their firm-specific human capital investments will not be assessed as being unique to that particular firm and where the market can 
reward them for such investments. Only in these companies, can an employee's prior firmspecific human capital investments act as a clear signal of their general human capital, and only in these settings can an employee expect to be able to appropriate more of the value that this general human capital can create.

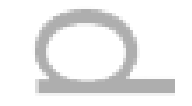

\section{DISCUSSION}

As suggested, the arguments developed in this paper have important implications for human capital and human resources scholarship. However, the arguments in the paper also can redirect scholarship on theories of the firm (Coase, 1937; Williamson, 1975) and the relationship between human capital and competitive advantage (Foss, 2011).

\section{Theories of the Firm}

Standard transactions cost theories of governance (Williamson, 1985) suggest that parties to an exchange often have incentives to make transaction-specific investments because such investments create value in that particular exchange that would not otherwise exist (Parmigiani and Mitchell, 2009). However, once one party in an exchange makes such investments, they are subject to opportunism by the other party precisely because transaction-specific investments have limited value in alternative settings. Thus, in order to realize the value associated with making transaction-specific investments, these exchanges are governed through hierarchical mechanisms, where market exchanges are replaced by managerial fiat. 
One understudied aspect of this theory of hierarchical governance is the signaling content of making transaction-specific investments that put one at risk of opportunism. In a way that parallels the arguments in this paper, such prior investments may, in some circumstances, signal a willingness and ability to make future transaction-specific investments. This willingness and ability is not a transaction-specific investment but is a valuable attribute in an exchange partner in any exchanges where such investments can create value. As one searches for potential exchange partners, identifying those partners who are willing and able to make transactionspecific investments is potentially very important.

Of course, to signal the willingness and ability to make transaction-specific investments in the future, these prior investments must not have been induced solely by hierarchical or other forms of governance in the past. Exchange partners who have made such investments in the past, despite the threat of opportunism, may be willing to make them in the future. Moreover, these exchange partners may not require costly hierarchical governance to make these value-creating investments. In this sense, these parties become attractive potential exchange partners.

But why would anyone make transaction-specific investments that put them at risk of opportunism? One answer may be that the signaling value of such investments may make them more attractive exchange partners in the future. At the least, the benefits of signaling that you are an attractive exchange partner in future exchanges needs to be balanced against the threat of opportunism that exists when "unprotected" transaction-specific investments are made in the first place. The conditions under which this signaling value is greater than the potential cost of opportunism is worthy of empirical work (Barney and Hansen, 1994). 


\section{Human Resources as a Basis of Competitive Advantage}

It has been recognized for some time that human capital has potentially important competitive implications for firms (Barney, 1986a). Unfortunately, much of the work on human capital and human resources has studied these phenomena at an aggregated level—at the level of

firm's HR policies and practices. When studied at this level, human capital differences among individuals are lost. But it is precisely these differences that are so important in the theory developed in this paper.

To address these issues, future work will need to explore human capital management at a much more micro level. This is already beginning to happen as some HR scholars have begun to recognize that two HR systems exist in many companies: the system for most employees, and the system for senior managers, and especially CEOs (Boudreau and Ramstad, 2005). Casual observation suggests these two systems are remarkably different - the one for most employees is often quite rigid and bureaucratic, the one for key senior managers is remarkably flexible.

One reason why these two systems may exist in parallel may be that senior managers have made more firm-specific human capital investments that are generally valuable, and thus their compensation reflects this special set of assets and thus must be more flexible and marketresponsive. Other employees may not have made such investments, and thus do not require the same kind of HR system (Boudreau et al., 2005).

\section{Future Research}


Testing the propositions developed in this paper is an important opportunity. Doing so will raise additional theory development and research opportunities. For example, theory is needed to explain whether value created from firm-specific human capital investments should be attributed to general human capital, firm-specific human capital, or some other contextualized form of human capital (Morris, Snell, and Bjorkman, 2016). That is, should the full value created from firm-specific human capital investments be attributed to the underlying general human capital? This is more than mere semantics because it could be that in some circumstances it is no longer useful or meaningful to distinguish between general and firm-specific human capital. Similarly, HR scholars will want to identify the psychometric constructs underlying the willingness and ability to make firm-specific human capital investments. Finally, qualitative research that extends received theories (e.g., Chadwick, 2006; Wang, et al., 2009) regarding the reasons why individuals make uncompensated firm-specific investments may prove insightful.

In this paper, the conditions under which apparently firm-specific investments can create a valued, yet difficult to observe form of general human capital — the willingness and ability to make firm-specific investments—are described. In so doing, the paper challenges prevailing wisdom that the implications of firm-specific and general human capital can be analyzed separately. The resulting theory redirects scholarship on value appropriation and employment relationships and opens important opportunities to revisit theories of the firm and competitive advantage. 




Acknowledgements: We would like to thank Ben Campbell, Russ Coff, Alison Mackey, Dave Kryscynski, Jeff Dyer, and Clint Chadwick for valuable comments and suggestions of earlier versions of this paper.

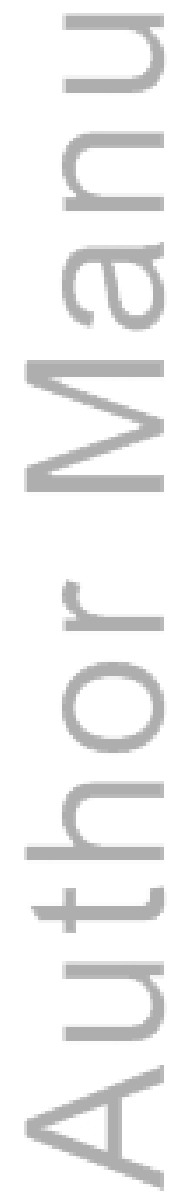




\section{REFERENCES}

Barney, JB. 1986a. Strategic factor markets: Expectations, luck and business strategy. Management Science 32: 1231-1241.

Barney, JB. 1986b. Organizational culture: can it be a source of sustained competitive advantage? Academy of Management Review 11: 656-665.

Barney, JB. 1991. Firm resources and sustained competitive advantage. Journal of Management 17: $99-120$.

Barney JB, Hansen M. 1994. Trustworthiness as a source of competitive advantage. Strategic Management Journal 15: 175-190.

Becker, GS. 1964. Human capital: A theoretical and empirical analysis, with special reference to education. Chicago: University of Chicago Press.

Bentler PM, Speckart G. 1979. Models of attitude-behavior relations. Psychological Review 86: $452-460$.

Boudreau JW, Ramstad P. 2005. Talentship, talent segmentation, and sustainability: A new HR decision paradigm for a new strategy definition. Human Resource Management 44: 129-136.

Campbell B, Coff R, Kryscynski D. 2012. Re-thinking competitive advantage from human capital. Academy of Management Review 37: 376-395.

Carmichael, L. 1983. Firm-specific human capital and compensation. Bell Journal of Economics, 14: $251-258$.

Chadwick, C. 2016. Towards a More Comprehensive Model of Firms' Human Capital Rents. Academy of Management Review, forthcoming.

Chadwick, C. 2006. The vital role of strategy in strategic human resource management education. Human Resource Management Review 15(3): 200-213.

Chadwick C, Dabu A. 2009. Human resources, human resource management, and the competitive advantage of firms. Organization Science 20(1): 253-272.

Coase, RH. 1937. The nature of the firm. Economica 4(16): 386-405. 
Coff R, Kryscynski D. 2011. Drilling for micro-foundations of human capital-based advantages. Journal of Management 37: 1299-1315.

Foss, NJ. 2011. Why micro-foundations for resource-based theory are needed and what they may look like. Journal of Management 37(5), 1413-1428.

Gardner, TM. 2005. Interfirm competition for human resources: Evidence from the software industry. Academy of Management Journal 48(2): 237-256.

Groysberg B, Lee L, Nanda A. 2008. Can they take it with them? The portability of star knowledge workers' performance. Management Science 54(7): 1213-1230.

Hatch NW, Dyer JH. 2004. Human capital and learning as a source of sustainable competitive advantage. Strategic Management Journal 25(12): 1155-1178.

Janz, T. 1982. Initial comparisons of patterned behavior description interviews versus unstructured interviews. Journal of Applied Psychology 67(5): 577-583.

Kang S, Morris SS, Snell SA. 2007. Relational archetypes, organizational learning, and value creation: Extending the human resource architecture. Academy of Management Review 32(1): $236-256$.

Lazear, EP. 2003. Firm-specific human capital: A skill-weights approach (No. w9679). National Bureau of Economic Research.

Lepak D, Takeuchi R, Swart J. 2011. Aligning human capital with organizational needs. In A. Burton-Jones, J. C. Spender (Eds.), Oxford Handbook of Human Capital: 647-670. Oxford, England: Oxford University Press.

Louis, M. 1983. Organizations as culture-bearing milieu. In L. Pondy, P. Forst, G. Morgan, T. Dandridge (Eds.), Organizational Symbolism: 186-218. JAI Press: Greenwich, CT.

Mackey A, Molloy J, Morris, S. 2013. Scarce human capital in managerial labor markets. Journal of Management 59: 436-442.

Molloy J, Barney J. 2015. Who captures the value created with human capital? A market-based view. Academy of Management Perspectives 29: 309-325.

Morris, S., Snell, S., Bjorkman, I. 2016. An architectural framework for global talent management. Journal of International Business Studies, forthcoming. 
Oldroyd J, Morris S. 2012. Stars that shine and stars that shimmer: A human resource response to social capital's detrimental effect on information overload for star employees. Academy of Management Review 37: 396-418.

Parmigiani A, Mitchell W. 2009. Complementarity, capabilities, and the boundaries of the firm: the impact of within-firm and interfirm expertise on concurrent sourcing of complementary components. Strategic Management Journal 30(10): 1065-1091.

Peteraf, MA. 1993. The cornerstones of competitive advantage: A resource-based view." Strategic Management Journal 14(3): 179-191.

Ployhart RE, Moliterno TP. 2011. Emergence of the human capital resource: A multilevel model. Academy of Management Review 36: 127-150.

Spence,M,1973. Job market signaling. Quarterly Journal of Economics 87(3): 355-374.

Wang HC, He J, Mahoney JT. 2009. Firm-specific knowledge resources and competitive advantage: The roles of economic- and relationship-based employee governance mechanisms. Strategic Management Journal 30: 1265-1285.

Williamson, OE. 1975. Markets and hierarchies: Analysis and antitrust implications. New York: Free Press.

Williamson, OE. 1985. The economic institutions of capitalism. New York: Free Press. Wright PM, Dunford BB, Snell SA. 2001. Human resources and the resource based view of the view. Journal of Management 27: 701-721.

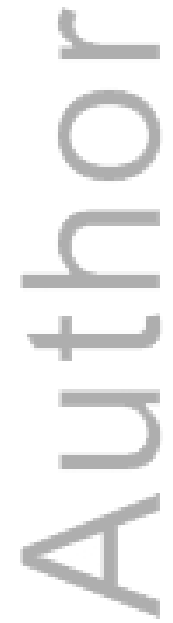

